\title{
Development of hydraulic binder using industrial wastes
}

\author{
GÁBoR MUCSI - University of Miskolc - ejtmucsi@uni-miskolc.hu \\ Ákos DEBRECZENI - University of Miskolc \\ VIKTOR MÁDAl - University of Miskolc \\ TímEA DUDOK - Carmeuse Hungary Co. Ltd. \\ BARNABÁs CSŐKE - University of Miskolc - ejtcsoba@uni-miskolc.hu \\ Received: 02.02.2011. - Érkezett: 2011.02.02. http://dx.doi.org/10.14382/epitoanyag-jsbcm.2011.6
}

This paper is focused on the utilization of landfilled $F$ class fly ash as a main component of hydraulic binder; furthermore quick lime $(\mathrm{CaO})$ and lime kiln dust (LKD) were tested as additives during the experiments. After determination of the material properties, such as particle size distribution, moisture content, real and bulk density and specific surface area, mechanical activation was performed for certain time by laboratory ball mill to improve the pozzolanic activity of fly ash. Than test specimens were produced using different type and composition of hydraulic binder and the compressive strength was measured at 14, 28 and 56 days. Optimal mechanical property was achieved with binder No. II. (containing $80 \%$ fly ash, 20\% CaO) and No. V. (70\% fly ash, 15\% CaO and 15\% LKD), compressive strength was 4.67 and $4.31 \mathrm{~N} / \mathrm{mm}^{2}$ respectively. Keywords: power plant fly ash, lime kiln dust, grinding, hydraulic binder

Dr. Gábor MUCS

is Assistant Professor at University of Miskolc, Institute of Raw Material Preparation and Environmental Processing since 2010. His main fields in education and research are mechanical processes - crushing and grinding, especially fine grinding - and utilization of industrial waste materials. He has 43 publications.

Dr. Ákos DEBRECZEN is Associate Professor at University of Miskolc Institution of Mining and Geotechnical Engineering since 1999. He has over 50 publications. His research areas are geomechanics, rock mechanics, investigation and improvement of tailings facilities, hydraulic and pneumatic transport

Dr. Viktor MÁDA is Assistant Professor at University of Miskolo, Department of Mineralogy and Petrology since 2005. Main research fields are silicate chemistry, and its environmental applications. He has 19 scientific papers and presentations.

Tímea DUDOK

is Marketing Expert at Carmeuse Hungary Co.

\section{Introduction}

According to the research experience of the Institute of Raw Material Preparation and Environmental Process Engineering, University of Miskolc quality-guaranteed fly ash based binder can be produced using $\mathrm{F}$ class ground fly ash and quick or hydrated lime powder mixed in appropriate ratio. The aim of the present work is how the above mentioned $\mathrm{CaO}$ and $\mathrm{Ca}(\mathrm{OH})_{2}$ can be replaced partially or fully with Lime Kiln Dust (LKD), a secondary raw material that generated in lime kiln plants in significant amount worldwide.

\section{Preliminaries}

Preliminary of this paper is a successfully implemented project started in 2005 (finished in 2007), namely the project entitled „Development of a technological system producing quality guaranteed fly-ash based binder" (GVOP-3.1.1-200405-0113/3.0). The main aim of the project was to develop a low-cost quality-guaranteed fly ash based binder especially for road construction (facilitating the construction of economical surface pavement). In the frame of the research laboratory and pilot plant experiments were carried out. The members of the consortium beside Institute of Raw Material Preparation and Environmental Process Engineering, University of Miskolc were as follows: H-TPA Innovation and Quality control Ltd., KTI Institute for Transport Sciences Non-profit Ltd. and IHU Industrial Waste Utilization Non-profit Ltd. The scientific coordinator was Prof. Dr. Barnabás Csőke.

Based on the results of the laboratory experiments it was stated that the pozzolanic activity of the investigated deposited fly ash samples, originated from four dumpsites, can be controlled by mechanical activation (grinding). One of them can be seen from Fig. 1. Furthermore, applicable hydraulic binder can be manufactured from industrial wastes (mainly fly ash) by adding adequate quantity of lime. The strength of specimens met the requirements of technical specifications, i.e.
Ltd since 2008. She graduated in 1997 at Sopron University as wood engineer (MSc) and in 2003 as Marketing Expert at the College of Foreign Commerce. Main fields are environmental (flue gas treatment and desulfurization) and construction industry (soil stabilization, hydrate in HMA).

Prof. Dr. Barnabás CsōKE is Professor at University of Miskolc, Institute of Raw Material Preparation and Environmental Processing. Research areas are mechanical processing, raw materials preparation, fracturemechanical and physical phenomena in fine disperse systems, research and development of processing techniques, modelling and simulation of comminution and separation processes, computer application in field of processing. He has over 150 publications.

it can be applied for building of road bedding. Thus a relative inexpensive binder can be produced using suitable raw material preparation technologies consists of grinding, classification, homogenization,... processes.

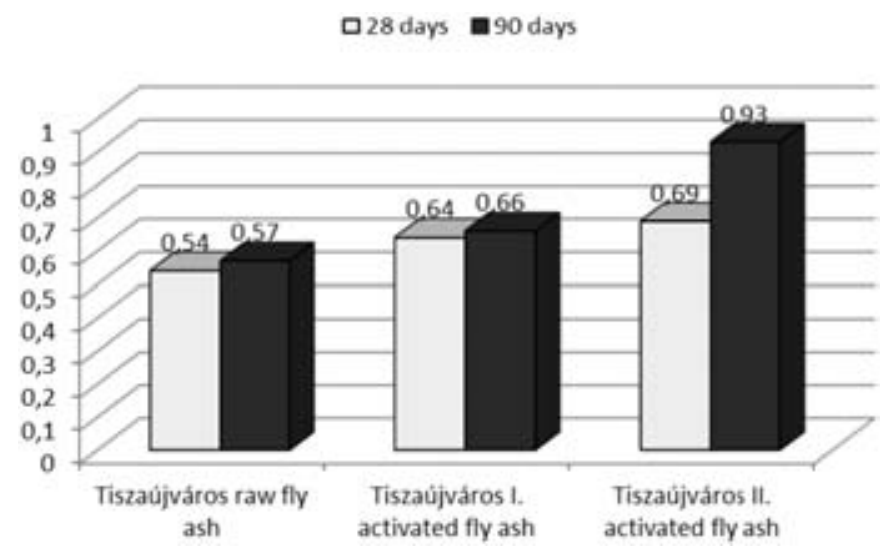

Fig. 1. Effect of mechanical activation on the activity index of Tiszaújváros fly ash (Mucsi et al., 2009)

1. ábra Mechanikai aktiválás hatása a tiszaújvárosi pernyeminta aktivitás indexére (Mucsi és szerzőtársai, 2009)

Two basic ideas led to start the present research of Lime Kiln Dust utilization. On the one hand from economic point of view the price of lime additive represents a significant amount in the production cost of the above presented fly-ash based hydraulic binder. This expense can be reduced using a 
lime coating secondary raw material. On the other hand from environmental point of view the treatment of a powdered byproduct (LKD) containing significant free lime can be solved by its application as a binder additive.

\section{About power station fly ash and LKD}

Fly ash is a pozzolanic powdery residue (mineral matter showing pozzolanic activity) collected in electric or mechanical dust collectors following combustion of coal in coal fired power plants. Fly ash is a finely dispersed material with average particle size between 10 to $30 \mu \mathrm{m}$. Particle size distribution of the fly ash depends on minerogenetic composition of the fuel coal the fineness of grinding and parameters of the system the fly ash was collected in. Hydraulic activity is one of the major characteristics of fly ash. The chemical reaction between $\mathrm{Ca}(\mathrm{OH})_{2}$ and the active component of fly ash (mainly reactive $\mathrm{SiO}_{2}$ ) leading to binding of the mixture is called pozzolanic reaction (Opoczky, 2001):

$\mathrm{x} \mathrm{Ca}(\mathrm{OH})_{2}+\mathrm{SiO}_{2}+\mathrm{mH}_{2} \mathrm{O}=\mathrm{xCaO} \cdot \mathrm{SiO}_{2} \mathrm{~m} \mathrm{H}_{2} \mathrm{O}$

Hydraulic activity of fly ash is governed by the totality of its physical and chemical properties. Most important factors are the chemical composition and phase structure, the degree of dispersion (particle size distribution and specific surface area) as well as the morphology of particles (see Fig. 2.).
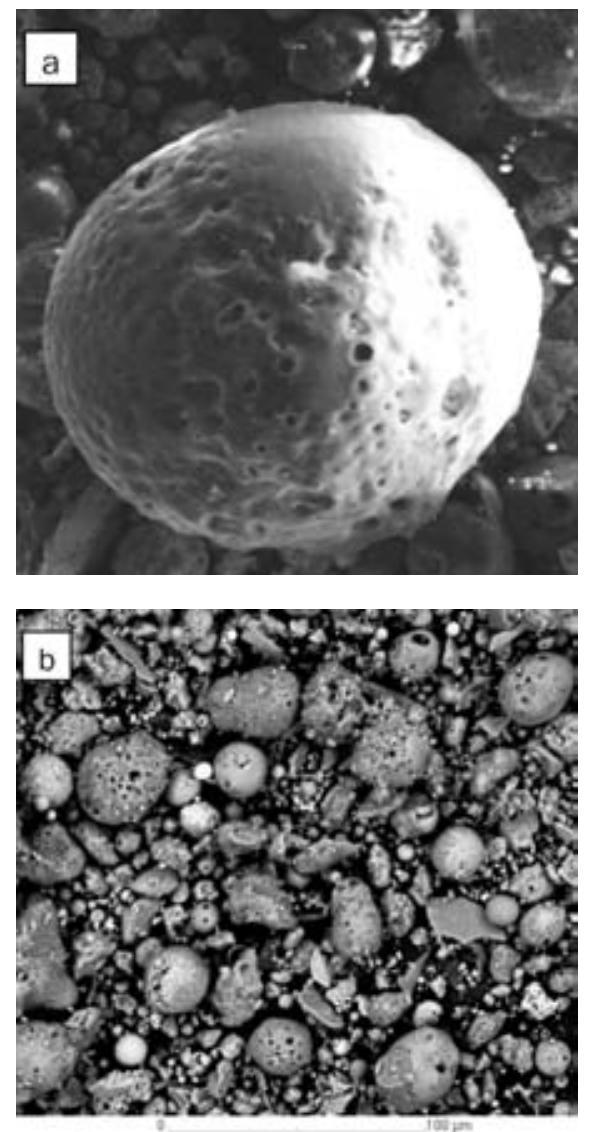

Fig. 2. a) and b) SEM images of fly ash

2. ábra a) és b) Pernye minták SEM felvételei

The amorphous (glassy) material of fly ash has important role in pozzolanic activity. Kusnierová et al. (2005) investigated the change of amorphous content of a black coal fly ash depending on time. They found significant devitrification in case of the previously landfilled fly ash, i.e. the ratio of glassy phase reduced. Namely the amorphous content of initial fresh fly ash of $90.65 \%$ reduced to $79.30 \%$ after 5 years, and to $67.70 \%$ after 20 years. During the progress mostly illite and zeolites are generated.

Muluken et al. (2009) investigated the chemical, mineralogical and geochemical properties of fly ash after landfilling for various durations and at various depths. The effects of weathering on the landfilled fly ash are studied in comparison with the fresh fly ash from the same site. The results shown the alternation in mineralogy and microstructure of the fly ash, and revealed the formation of secondary minerals (calcite and ettringite) mainly due to hydration, carbonation and pozzolanic reactions.

Regarding the origin of the fly ash they can be generated from the burning of lignite, brown and black coal, as for collection method they are filter or cyclone fly ash.

Utilization of fly ash and lime kiln dust as raw material is of common interest, since beside the users, the power plant and lime plant owners can benefit significantly by reducing the amount of material to be treated and stored. Furthermore the population would have advantages as well by exempting valuable fields at the place of dumpsites. The rational primary raw material (limestone, dolomite, clay, sand, etc...) management is of great importance, additional advantage is to save the mineral deposits and to reduce the energy input for their preparation as well as to diminish the $\mathrm{CO}_{2}$ emission.

According to the results of the international research work it can be stated that the utilization of fly ash in the concrete industry has the following advantages:

- Better workability, due to the spherical particles the viscosity of the concrete mixture will be better.

- The strength of the concrete can be improved by filling the pores by small fly ash particles (filler effect).

- The heat of hydration is reduced.

- The waterproofing is improved.

- The fluid concrete can be pumped easier.

- Better insulation effect can be reached.

- The efflorescence generated by $\mathrm{Ca}(\mathrm{OH})_{2}$ and salts can be diminished.

The above presented material characteristics can be modified by using the appropriate raw material preparation technologies and processes (grinding, classification, enrichment). The concrete produced by this way have favorable properties from economic and environmental aspects as well.

During the calcination of limestone significant amount of dust by-product is generated, which called lime burning dust or lime kiln dust (LKD) collected in electrofilter. Different types of dust control equipment are used, but basically the systems can be classified as either wet or dry. The chemical composition of LKD from high-calcium lime plants varies widely depending on factors such as the physical and chemical characteristics of the limestone used, the type of kiln used, whether a preheater is used, operating parameters of the kiln, reactivity of the lime 
produced, and chemical composition of the fuel used. The LKD material may contain roughly equal amounts of free/available $\mathrm{CaO}$ and uncalcined calcium carbonate, and lesser amounts of impurities such as $\mathrm{MgO}$ derived from the limestone.

However, the landfilling of such material is complicated and not favorable from environmental aspect because of its high free lime content. Therefore an environmental friendly solution would be the utilization of LKD in inert form, for instance as an activating additive for low free lime content binders. For this opportunity it is necessary to know the hydration behavior and chemical/mineralogical composition of the raw by-product.

\section{Materials}

\section{Fly ash}

The brown coal fly ash sample investigated is originated from the Tiszaújváros dumpsite which was landfilled few decades ago and probably during this period the material was passivated, i.e. the amorphous, glassy phases are partially recrystallized spontaneously. The amorphous content was found to be $23.00 \%$.

The material fineness can be characterized by median of $\mathrm{x}_{50}$ $=48.58 \mu \mathrm{m}$ and specific surface area of $\mathrm{S}_{\mathrm{m}}=2664.65 \mathrm{~cm}^{2} / \mathrm{g}$, its density is $1960 \mathrm{~kg} / \mathrm{m}^{3}$. Based on our earlier experience, we decided to use an activated fly ash (20 min ball milled) for experiments. The ground material has $7931.16 \mathrm{~cm}^{2} / g$ of fineness. Since the raw material had $21.63 \%$ initial moisture content, the fly ash was dried in a drying cabinet before grinding.

The chemical composition of fly ash shows $85.20 \%$ combined $\mathrm{SiO}_{2}$ and $\mathrm{Al}_{2} \mathrm{O}_{3}$ content and $2.30 \% \mathrm{CaO}$ content.

\section{Lime kiln dust}

Carmeuse Hungary Co. Ltd. provided two different LKD samples for experiments, one from Hungary and another from Czech Republic. Before the laboratory tests X-Ray Diffraction measurements were carried out using a Bruker D8 Advance apparatus in the laboratory of Department of Mineralogy and Petrology (University of Miskolc). Results can be found in Table 1. The main phases are calcite $\left(\mathrm{CaCO}_{3}\right)$, portlandite $\left(\mathrm{Ca}(\mathrm{OH})_{2}\right)$, lime $(\mathrm{CaO})$ and tobermorite $\left(\mathrm{Ca}_{5}\left(\mathrm{Si}_{6} \mathrm{O}_{16}\right)(\mathrm{OH})_{2}\right)$ was detected in minor quantity. The moisture content of the Hungarian and the Czech sample was $0.77 \%$ and $0.60 \%$ respectively.

\begin{tabular}{lcc} 
& Hungarian sample & Czech sample \\
$\mathrm{CaCO}_{3}$, calcite, \% & 78.40 & 27.80 \\
\hline $\mathbf{C a}(\mathbf{O H})_{2}$, portlandite, \% & 21.60 & 3.20 \\
\hline $\mathbf{C a O}$, lime, \% & 0.00 & 64.50 \\
\hline $\begin{array}{l}\mathbf{C a}_{5}\left(\mathbf{S i}_{6} \mathbf{O}_{16}\right)(\mathrm{OH})_{2} \\
\text { tobermorite } 9 \mathbf{9 A}, \%\end{array}$ & 0.00 & 4.50 \\
\hline
\end{tabular}

Table 1. Mineral composition of LKD samples

1. táblázat Mészégetési por minták (LKD) ásványos összetétele

The high calcite $\left(\mathrm{CaCO}_{3}\right)$ content of the Hungarian sample $(78.40 \%)$ is probably the result of the incomplete burning of the limestone, the presence of portlandite $(21.60 \%)$ can be explained by the hydration of the $\mathrm{CaO}$ due to the humidity of air. In the case of the Czech sample the lime $(\mathrm{CaO})$ content is relatively high $(64.50 \%)$ and small amount of $\mathrm{Ca}(\mathrm{OH})_{2}$ (product of hydration) can be detected as well. The tobermorite mineral of the Czech sample was supposedly present in the raw limestone due to the natural hydrothermal conversion or a $\mathrm{Si}$ coating phase reacted with $\mathrm{CaCO}_{3}$ during the calcination.

There is significant difference between the mineral composition of the LKD samples, which result from the operating and machine parameters of the technology using for lime calcination and the handling of the lime burning secondary raw material.

The particle size distribution of the samples was measured by a laser diffraction particle size analyzer (Fritsch Analysette 22). The Hungarian sample is of $x_{50}=29.79 \mu \mathrm{m}$ median and $\mathrm{x}_{80}=81.97 \mu \mathrm{m} 80 \%$ passing size, the Czech sample have $\mathrm{x}_{50}=17.82 \mu \mathrm{m}$ and $\mathrm{x}_{80}=40.01 \mu \mathrm{m}$.

The applied lime sample was a conventional lime produced by Carmeuse Group in the Miskolc Hejöcsaba plant. It can be characterized with following parameters: maximum particle size $\mathrm{x}_{\max }=2 \mathrm{~mm}$, density $\rho_{\text {bulk }}=0.8 \mathrm{~g} / \mathrm{cm}^{3}, \mathrm{CaO}$ content $90 \mathrm{~m} / \mathrm{m} \%$, reactivity: $60^{\circ} \mathrm{C}$ reached during $120 \mathrm{~s}$.

\section{Experimental}

In order to realize the previously presented aims the following systematic experimental series were carried out regarding the applicability determination of mechanically activated fly ash, $\mathrm{CaO}$ and Hungarian lime kiln dust as component of hydraulic binder. Firstly, binder mixtures of ground fly ash and lime were produced in different ratios (see Table 2.), than mixing it with water and sandy gravel aggregate $(\mathrm{x}<20 \mathrm{~mm})$ was conducted, finally cylindrical concrete specimens were formed. After removing them from the mould the specimens were kept under appropriate circumstances and mechanical strength was determined by an uniaxial compression testing machine at the age of 14,28 and 56 days.

\begin{tabular}{|c|c|c|c|c|}
\hline $\begin{array}{l}\text { Number of } \\
\text { experiment }\end{array}$ & & Ratio [\%] & & Ratio [\%] \\
\hline I. & \multirow{5}{*}{ Fly ash } & 85 & \multirow{2}{*}{$\mathrm{CaO}$} & 15 \\
\hline II. & & 80 & & 20 \\
\hline III. & & 85 & \multirow{2}{*}{$\begin{array}{c}\text { LKD } \\
\text { (Hungarian) }\end{array}$} & 15 \\
\hline IV. & & 80 & & 20 \\
\hline V. & & 70 & $\begin{array}{l}\mathrm{CaO}+\mathrm{LKD} \\
\text { (Hungarian) }\end{array}$ & $15+15$ \\
\hline
\end{tabular}

Table 2. The composition of the hydraulic binder 2. táblázat A hidraulikus kötóanyag keverékek összetétele

Nine pieces of cylindrical specimens were produced per composition since the strength of the bodies was determined at three ages. The amount of the binder to the concrete was 170 $\mathrm{kg} / \mathrm{m}^{3}$ during the experiments.

The preparation of the specimens and the implementation of the compressive tests were completed in accordance with MSZ EN 13286-41 and MSZ EN 13286-42 in the laboratory of the Institution of Mining and Geotechnical Engineering (University of Miskolc). The dimensions of the cylinders (Fig. 3.) were $\varnothing 102 \times 115 \mathrm{~mm}$. Accordant to the Technical Specification UT 
2-3:207 regulations the compacting of the concrete specimens were conducted using a proctor device.

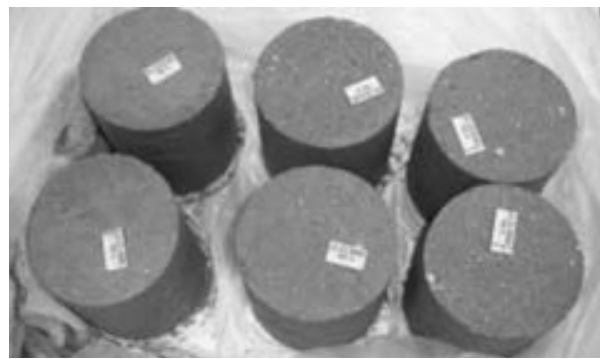

Fig. 3. Cylindrical concrete specimens

3. ábra Hengeres beton próbatestek

\section{Results}

Fig 4. shows the change of compressive strength as function of age in case of the presented binder mixtures. It can be established from the test results that the fly ash-LKD type binders have the lowest strength (III. and IV. experimental series). In these cases 0.21 and $0.58 \mathrm{~N} / \mathrm{mm}^{2}$ maximum values were measured respectivelyat the age of 56 days.

On the contrary the compressive strength shows significantly higher values using the conventional lime produced by Carmeuse Group. The strength resulted at 56 days reached 4.67 $\mathrm{N} / \mathrm{mm}^{2}$ in the measurement serie No. II. (80\% fly ash $-20 \%$ $\mathrm{CaO})$, which is a relatively high value. However, only slight difference from that was found using the binder No. V. (70\% fly ash - 15\% CaO - 15\% LKD), it was $4.31 \mathrm{~N} / \mathrm{mm}^{2}$.

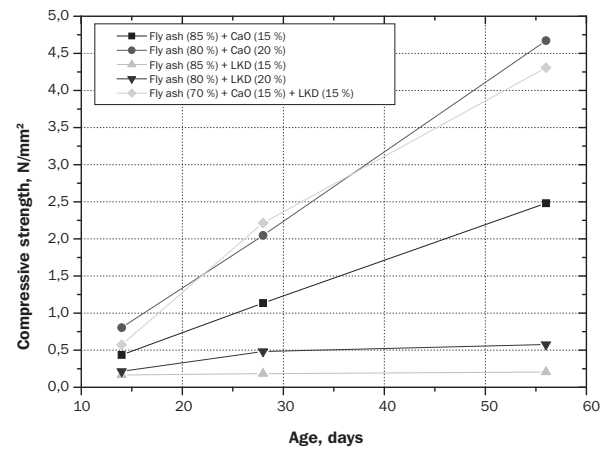

Fig. 4. Compressive strength of specimen as function of age

4. ábra Próbatestek nyomószilárdsága a vizsgálati kor függvényében

Furthermore, comparing the hardening process of the concrete specimens containing different binders shown in Table 2., it can be seen a greatly slower solidification in case of LKD coating bodies than that of $\mathrm{CaO}$ and $\mathrm{CaO}-\mathrm{LKD}$ containing specimens. Probably, it can be explained by the result of the low content of free lime in case of lime burning by product, i.e. pozzolanic reaction generates weak calcium-silicate-hydrate product.

Regarding the coefficient of standard deviation of compressive strength considerable fluctuation can be seen (Fig. 5.), the curves are of diverse shape. Coefficient of standard deviation containing LKD shows lower value.

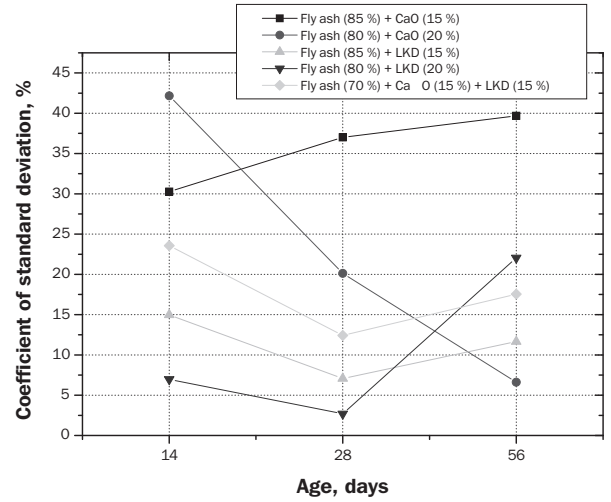

Fig. 5. Coefficient of standard deviation of compressive strength as function of age 5. ábra Nyomószilárdság szórási együtthatóinak változása a vizsgálati kor függvényében

\section{Conclusions and suggestions}

Based on the results of the laboratory experiments the following statements can be created:

- Regarding the XRD results of the lime kiln dust (LKD) large diversity was found in the composition of the samples. Characteristic minerals were calcite, portlandite and lime.

- From the compressive strength results it was established that the binder containing $80 \%$ fly ash and $20 \% \mathrm{CaO}$ had the highest compressive strength at age of 14 days $\left(0.80 \mathrm{~N} / \mathrm{mm}^{2}\right)$, the lowest strength belongs to the mixture of $85 \%$ fly ash and $15 \% \operatorname{LKD}\left(0.17 \mathrm{~N} / \mathrm{mm}^{2}\right)$.

- The hardening of the concrete specimens, as usual like the fly ash containing binders, shown significant after-hardening. The strongest concrete specimens were produced from binder No. V (70\% fly ash, 15\% CaO and $15 \% \mathrm{LKD})$ at 28 days $\left(2.20 \mathrm{~N} / \mathrm{mm}^{2}\right)$. At the age of 56 days the highest compressive strength was $4.67 \mathrm{~N} /$ $\mathrm{mm}^{2}$ of mixture No. II ( $80 \%$ fly ash and $\left.20 \% \mathrm{CaO}\right)$.

- Due to the significant after-hardening of the concrete containing the presented binder it is suggested to extend the aging time to 84 and 168 days as well.

- The stability of LKD-containing specimens (without lime) increased only slightly as function of age and after a certain value the strength almost stagnated. On the other hand in the case of binders with lime and lime + LKD remarkable strength development could be seen.

- In this way the lime kiln dust by-product may be a possible secondary raw material. Of course, the above results are the outcome of the preliminary investigation of lime kiln dust (LKD) utilization as binder additive, it is proposed to continue the research with further experiments (leaching tests, other LKD samples,...).

- In the light of the results the suggested utilization opportunities are as follows: production of lean mixed concrete, stabilization of sandy soils, building capping layer and stabilized embankment.

- Since the quality of the possible secondary raw material is very diverse, their regular physical and chemical controlling is essential in order to produce a quality 
guaranteed final product. From this point of view the most important material characteristics are as follows: pozzolanic activity, content of amorphous $\mathrm{SiO}_{2}, \mathrm{SO}_{3}$ content, loss on ignition, free lime, particle size distribution, density, and morphology. Most of the above properties can be upgraded using the appropriate process engineering technologies.

\section{References}

[1] Csőke B. - Mucsi G. - Opoczky L. - Gável V.: Modifying the hydraulic activity of power station fly ash by grinding. Cement International No. 6/2007. Vol. 5. ISSN 1610-6199 pp. 86-93.

[2] Csőke B. - Mucsi G. - Sík Cs.: Production and practical application of mechanically activated fly ash-based binding material. $\mathrm{VI}^{\text {th }}$ International Conference on Mechanochemistry and Mechanical Alloying 1-4 December 2008, Jamshedpur, India

[3] Csőke B. - Mucsi G. - Sík Cs. - Gáspár L.: Fly ash based road construction binder. II International Conference on Environmentally Friendly Roads, Warsaw, 15-16 October 2009. CD-ROM Proceedings. 10 p.

[4] Csőke B. - Mucsi G. - Karoliny M. - Sík Cs. - Gáspár L. - Erős Gy.: Ground fly ash and lime hydrate based quality guaranteed binder. (In Hungarian: Minőség-garantált őrölt pernye és mészhidrát-bázisú kötőanyag.) Invention: P0700644.

[5] Csőke B. - Mucsi G. - Karoliny M. - Sík Cs. - Gáspár L. - Erős Gy. - Juhász I.: Process and machine for production of ground fly ash and lime hydrate based quality guaranteed binder (In Hungarian: Eljárás és berendezés minőség-garantált örölt pernye és mészhidrát-bázisú kötőanyag elöállitására). Invention: P0700645.

[6] Development of a technological system producing quality guaranteed fly-ash based binder. (2007) GVOP-3.1.1-2004-05-0113/3.0 project, final report

[7] Gáspár L.: Secondary raw materials in the road building (In Hungarian: Másodlagos nyersanyagok az útépitésben). 2005 Budapest, IHU Kht.

[8] HU ISSN: 0522-3512

[9] Kusnierová M. - Slesárová A. - Prascáková M.: The significance of fly ash for their processing and utilization. In. Proc. Waste Recycling - IX. Krakow, 17-19. November 2005.

[10] Mucsi G. - Csőke B. - Gál A. - Szabó M.: Mechanical activation of lignite fly ash and brown coal fly ash and their use as constituents in binders. Cement International No. 4/2009 Vol7., ISSN 1610-6199 pp. 76-85.
[11] Muluken B. Yeheyis - Julie Q. Shang - Ernest K. Yanful: Chemical and Mineralogical Transformations of Coal Fly Ash after Landfilling. 2009. World of Coal Ash Conference (WOCA), May 4-7, 2009. Lexington, Kentucky, USA

[12] Opoczky L.: Silicate-chemical properties of fly ash. "For our clear environment scientific conference. (In Hungarian: A pernyék szilikátkémiai tulajdonságai. „Tiszta Környezetünkért” Szénerömüi pernyék hasznosításával tudományos konferencia.) Miskolci Egyetem, A. Bányászat 55. Kötet. Környezetvédelem, eljárástechnika . HU ISSN 0237-6016.p. 97-108 (2001)

[13] Szilágyi K. - Gömze A. L. - Polacsek G.: Investigation and determination of the admixture ratio of fly ash aiming at the optimization of mechanical properties of the cement produced. (In Hungarian: A pernye bekeverési arányainak vizsgálata, meghatározása a gyártott cement mechanika tulajdonságainak optimalizálása céljából.) Építőnyag 2008/2. pp. 44-48.

Ref.: http://dx.doi.org/10.14382/epitoanyag-jsbcm.2011.6 Gábor Mucsi - Ákos Debreczeni - Viktor Mádai - Tímea Dudok Barnabás Csőke: Development of hydraulic binder using industrial wastes. Építőanyag, 63. évf. 1-2. szám (2011), 28-32. p.

Hidraulikus kötőanyag fejlesztése ipari hulladékokból Jelen cikk egy deponált savanyú erômúi pernye hasznosításával foglalkozik, mint hidraulikus kötőanyag fố komponense. Ezen túlmenōen égetett mész ( $\mathrm{CaO})$ és mészégetési szállópor (LKD) adalékanyag alkalmazhatóságát vizsgáltuk a kísérletek során. Az alapanyagok tulajdonságainak - úgymint szemcseméret eloszlás, nedvességtartalom, valódi- és halmazsúrúség és fajlagos felület - meghatározását követôen bizonyos ideig tartó mechanikai aktiválást hajtottunk végre laboratóriumi golyósmalomban a pernye puccolános aktivitásának javítása érdekében. Ezután beton próbatesteket gyártottunk a különbözố típusú és összetételû hidraulikus kötőanyagokból, és megmértük azok nyomószilárdságát 14, 28 és 56 napos korban. Optimális tulajdonságokat a II. (80\% pernye és 20\% CaO) és az V. számú (70\% pernye, 15\% CaO és 15\% LKD) kötôanyag keverékeket alkalmazva értünk el, amikor is 4,67 és $4,31 \mathrm{~N} / \mathrm{mm}^{2}$ nyomószilárdság értéket kaptunk.

Kulcsszavak: erômúi pernye, mészégetési szállópor, ôrlés, hidraulikus kötôanyag

\section{Hírek a Szigetelő Szakosztály Életéből}

- Az SZTE Szigetelô Szakosztálya 2010. július 15-én kibóvített vezetôségi ülést tartott. Az ülésen megtárgyalták az SZTE helyzetét és az ezzel kapcsolatos tennivalókat. Az Egyesület rossz anyagi helyzete miatt a Konferenciaközpontból el kellett költözni, így a vezetôségi ülés egyben a régi irodától való búcsút jelentette. A Szakosztály örökös tiszteletbeli elnöke, Dr. Rudnyánszky Pál megköszönte Tóth-Asztalos Réka és Dr. Antal Józsefné, Betty eddigi eredményes munkáját. A kibôvített vezetôségi ülésen utoljára volt közöttünk a Szakosztály azóta sajnálatosan elhunyt korábbi elnöke, Pataky Elemér, a résztvevốkrốl készült csoportképen ô is látható.

- A Szakosztály elnöke, Regenhart Péter beszámolt az Európai Szigetelési Vállalkozók Szövetségének (European Federation of Association of Insulation Contractors) Olaszországban, Comoban tartott közgyûlésérôl és az ipari hôszigetelô szakmai képzés hazai helyzetérôl. Azóta megjelent a Kormány 29/2011. (III. 11.) sz. rendelete az Országos Képzési Jegyzék módosításának eljárásrendjérôl, amely az „Ipari szigetelō-bádogos” szakképzést az OKJ-be felvette.
- Az Európai Szigetelési Vállalkozók Szövetsége (European Federation of Association of Insulation Contractors) 2011. május 5-6-án Bécsben tartotta tavaszi megbeszélését, amelyen többek között, az ipari szigetelési munkákat szabályozó dokumentumok módosítását, a 2012. évi, Berlinben megrendezésre kerülố Európai Szakmunkástanuló Verseny szabályzatát és részvételi feltételeit vitatták meg. Ezen a megbeszélésen Regenhart Péter vett részt és részletes beszámolót tart róla a Szakosztály június elsố felében tartandó taggyúlésén.

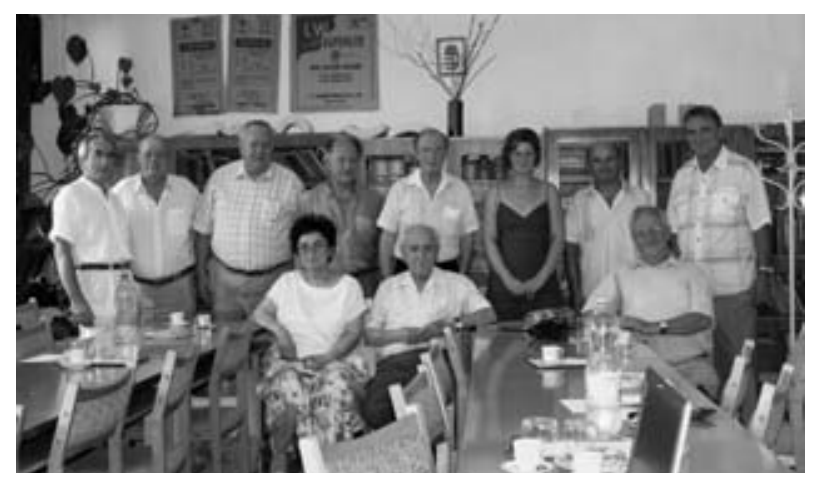

